\title{
THE GAP BETWEEN THE MUSEUMS AND CONTRACT ARCHAEOLOGY
}

\section{Göran Gruber}

Stenbrötsgatan 10, 58247 Linköping, Sweden

goranfgruber@gmail.com

I am part of a research project, a pilot study, with the title FuTArk Funktionsvariation, Tillgänglighet, Uppdragsarkeologi (Dis-/ability, Accessibility, Contract Archaeology). The starting point for the project is that all people have the right to share in the past and participate in heritage processes on equal terms. In that context contract archaeology must be seen as a practice that ought to be available to everyone in the society. The question we ask is whether this actually is a reality. The project particularly focuses on the relation between contract archaeology and people with various disabilities. We know very little about this today even though our experiences indicate shortcomings when it comes to attitude, knowledge, as well as activities.

As part of the pilot study we conducted a survey during the spring of 20I7. It was aimed at members of Sveriges Uppdragsarkeologiska Branschorganisation (SUBo) and Museiarkeologiska branschorganisa- 
tionen (M-ark). ${ }^{\mathrm{I}}$ Our purpose was to get a quick overview of how the institutions within these associations handle questions concerning dis-/ ability and accessibility. I won't go through the results of the survey here. But in relation to the keynote discussion for this volume of CSA, it is interesting to see how museums within both these associations articulated their answers. They expressed themselves in three different ways (Engström 20I7):

- They described the way they handled dis-/ability issues on an overall level and in that context the contract archaeology functions within the museum were not visible at all.

- They described the way they handled dis-/ability questions on an overall level but with the addition that the answers were not relevant for the contract archaeological function within the museum.

- They only described how their contract archaeological function handled dis-/ability questions and made no relation to the general functions of the museum.

The way the museums answered this survey makes a split visible between the museum's general functions and their contract archaeological functions. This gap is not a novelty per se but a fact that is accentuated in the keynote discussion. There is a passage in the article that can be viewed as a way for us to understand this gap. It refers to the relation of contract archaeology to the goals of national culture policies and the goals of the cultural environment sector (kulturmiljövården) while also showing that there is a call from official authorities for a contract archaeology that 'has broader purposes and responsibilities besides excavating, documenting and doing research' (Högberg \& Fahlander, this volume)

This quotation reflects an important conceptual change within the cultural heritage sector, to extend goals beyond the 'self-formulated intra-sector' ones traditionally practiced. For a long time we have seen this change in the museum sector, although it is not as apparent in the

1 SUBo (Swedish Contract Archaeological Trade Association) 'is a trade association for organizations pursuing contract archaeology, including both public and private performers. The purpose is to act for fair and favourable terms nationally, and to make the social benefit of cultural environment work visible.' (Sveriges Uppdragsarkeologiska Branschorganisation n.d.). M-ark (Museum Archaeological Trade Association) is an association for regional and municipal museum archaeology. The purpose is 'to support members in their work with developing, building up and communicating archaeological knowledge which contributes to social relevance. In short, a socially healthy archaeology for everyone' (Museiarkeologiska branschorganisationen n.d.). The survey was sent to all members of both organizations, in total 26. Several museums are members of both organizations. 
practices of contract archaeology. In the long run this creates tension, with the result that the functions within the museums are slowly gliding apart from each other.

\section{GOALS, STRUCTURE, ECONOMY}

The goals for the regional museums have changed in recent decades. Formerly their main task was to collect artefacts and data concerning people's way of living in ancient/past times and display these artefacts, thus creating narratives about an imagined national (and/or regional) community. One example of this is the way the narrative of Swedish prehistory was articulated in the main exhibition of the National Historical Museum in Stockholm and how this notion got provincial replicas in different regional museums over the country. In recent years the goals of the museums have widened. Today regional, as well as national, museums are driven by multicultural and democratic perspectives (for example Sörmlands museum n.d.; Bohusläns museum n.d.). During the last few decades public communication (förmedling in Swedish), in the sense of one-way communication, has been problematized from a participation perspective. The same goes for the concept of cultural heritage, whether it is something we can point to or if it is created through our current use of the past.

In the local/regional rhetoric, museums are expected to provide perspective on the past as well as the present for a desired future. In that regard the museums are viewed as meaningful creative and cultural forces in place marketing when, say, churches, ruins of monasteries and castles related to the medieval past of the province of Östergötland, Sweden, are staged as sites for the tourist gaze (Gruber 20IO).

Contract archaeology, in contrast, is formulated as a national practice even if the antiquarian work is done in a local/regional context. In recent decades we have witnessed how the government has repeatedly searched for new arguments to legitimize a contract archaeology that relies on legislation where the developer is singled out as liable for the costs:

- During the I990s the government argued for a mission to widen the practice and include scientific research as part of the antiquarian work with excavations and documentation. In the internal rhetoric of today, contract archaeology is a recognized form of scientific research! Meanwhile it may be noted that the scientific interpretations rarely become part of the museums' exhibitions. 
- During the early 2000 s the focus was on turning contract archaeology into a competitive market. Among many things, this has had the result that publicly funded parts of the museums no longer can be a part of contract archaeology projects since this makes for an unequal market. One way of solving this has been to create tariffs for internal billing.

- During the 2oros the wider social values of contract archaeology have received some attention, which in turn has meant that the heritage act has been adjusted and nowadays also enables public events, or communication (förmedling)!

In the local/regional context it goes without saying that the museums should be a part of different networks (for example Jönköpings läns museum 20I5). The contract archaeological practice is a part of the same networks but unfortunately these interactions seldom have the opportunity to develop. Instead they are hampered since contract archaeology is locked within an idea that the practice is a tripartite system consisting of the developer, the decision-making authorities and the contractors (archaeologist). In this system the citizens are reduced to passive receivers of the results that the archaeologists create (Arnberg \& Gruber 20I4). The barriers towards the citizens are amplified further as a result of the successive professionalization that the sector has undergone due to the marketization. However, this does not seem to be a prioritized problem within the political rhetoric. The focus has rather been on creating a contract archaeology sector consisting of as many different contractors as possible. Today we see a wide range of contract archaeology institutions - corporations, foundations, cooperatives, museum units. Diversity has thereby been created within contract archaeology practice while the tripartite system has been maintained.

\section{CONCLUSION}

One could state that while the museums are in a local/regional political context and function through wide networks, the contract archaeologists who work within the museums are part of a professional management practice that is regulated by law. While the museums in general strive to live up to the diversity and participation goals of cultural policy, the practice in contract archaeology is wobbling around trying to figure out how to manage to be antiquarian, scientific, marketable and public. Within the museums this creates tension of an ideological, legal, structural and economic character. Despite this dilemma there are some museums that 
have chosen to doggedly continue working with contract archaeology and maintaining the archaeological competence in-house. Others have chosen to dispose of this museum function, or to lay off part of the staff. This has in turn led to more new, small contract archaeology companies. Further museums have tried to find new operation areas of activities and/or collaborations which include their contract archaeologists.

The changes we have seen in the museum field in combination with an increasingly complex contract archaeology raises questions as to whether there is a place for the latter in the museums of today. If not, will the baby be thrown out with the bathwater now that the Swedish Heritage Act emphasizes public communication as part of the contract archaeology practices?

\section{REFERENCES}

\section{Literature}

Arnberg, A. \& Gruber, G. 20I4. Participate in a broader sense? Thoughts on Swedish contract archaeology and approaches to the public in the light of the excavations in Motala 1999-2013. Current Swedish Archaeology. Vol. 22. Pp. I57-182.

Engström, E. 2017 (ms) FuTArk - Funktionsvariation, Tillgänglighet, Uppdragsarkeo$\log i$, report.

Gruber, G. 20Iо. Medeltider: Samtida mobiliseringsprocesser kring det förflutnas värden. Diss. Linköping: Linköpings universitet.

\section{Internet sources}

Bohusläns museum. n.d. Våra värderingar. Uddevalla: Bohusläns museum. [online] Availible at: <http://www.bohuslansmuseum.se/om-oss/vara-varderingar/> [Accessed 4 August 2017].

Jönköpings läns museum. 20I5. Verksamhetsplattform 20I5-20I8. Jönköping: Jönköpings läns museum. [online] Availible at: <http://www.jkpglm.se/box-ommuseetr/Om-museet/Verksamhetsplattform-20I5-20I8/> [Accessed 4 August 20I7].

Museiarkeologiska branschorganisationen (M-ark). n.d. Välkommen till Museiarkeologiska branschorganisationen! Halmstad: Museiarkeologiska branschorganisationen. [online] Availible at: <http://www.m-ark.se/> [Accessed ${ }_{4}$ August 20I7].

Sveriges Uppdragsarkeologiska Branschorganisation (SUBo). n.d. Kulturmiliö och kulturarv. Stockholm: Sveriges Uppdragsarkeologiska Branschorganisation. [online] Availible at: <http://uppdragsarkeologi.se/> [Accessed 4 August 20I7].

Sörmlands museum. n.d. Sörmlands museums vision. Nyköping: Sörmlands museum. [online] Availible at: <http://www.sormlandsmuseum.se/om-oss/vision-ochkannetecken/> [Accessed 4 August 20I7]. 